\title{
Peran Keluarga pada Perkembangan Moral Siswa SD di Lingkungan Eks Lokalisasi
}

\author{
Rona Wahyuningsih ${ }^{1}$, Fattah Hanurawan ${ }^{2}$, Ramli $^{3}$ \\ ${ }^{1}$ Pendidikan Dasar-Universitas Negeri Malang \\ ${ }^{2}$ Pendidikan Psikologi-Universitas Negeri Malang \\ ${ }^{3}$ Bimbingan dan Konseling-Universitas Negeri Malang
}

\section{INFO ARTIKEL}

\section{Riwayat Artikel:}

Diterima: 22-08-2019

Disetujui: 12-05-2020

\section{Kata kunci:}

family role; moral development; elementary student; peran keluarga; perkembangan moral; siswa $S D$

\author{
Alamat Korespondensi: \\ Rona Wahyuningsih \\ Pendidikan Dasar \\ Universitas Negeri Malang \\ Jalan Semarang 5 Malang \\ E-mail: ronawahyuningsih@gmail.com
}

\begin{abstract}
ABSTRAK
Abstract: This article aims to look at the role of family in the moral development of children in the former localization environment. This research was conducted in January at Ngujang 2 Elementary School located in Kedungwaru Sub-district, Tulungagung regency with the subject of 2 students 'with different family conditions. This research use a qualitative research method of case study type. Data collection starts from observation, interviews, and documentation. The findings show that the role of the family environment in child moral development is crucial. Each child's family will get science that is not found in formal educational. The family environment plays a role in organizing a child's life. Organizing your children will grow in everyday life. The family environment becomes a foundation in every child development. Good and bad in child development is also determined the role gained from the family.

Abstrak: Artikel ini bertujuan untuk melihat peran keluarga dalam perkembangan moral anak di lingkungan eks lokalisasi. Penelitian ini dilakukan pada bulan Januari di SDN 2 Ngujang yang berlokasi di Kecamatan Kedungwaru, Kabupaten Tulungagung dengan subjek penelitian dua orang siswa dengan keadaan kondisi keluarga yang berbeda. Penelitian ini menggunakan metode penelitian kualitatif jenis studi kasus. Pengumpulan data dimulai dari observasi, wawancara, dan dokumentasi. Temuan menunjukan bahwa peran lingkungan keluarga dalam perkembangan moral anak sangat penting. Keluarga setiap anak akan mendapatkan ilmu yang tidak ditemukan di lingkungan pendidikan formal. Lingkungan keluarga berperan dalam mengatur kehidupan seorang anak. Mengatur bagimana anak akan tumbuh berkembang dalam kehidupan sehari-hari. Lingkungan keluarga menjadi pondasi dalam setiap perkembangan anak. Baik buruk perkembangan anak juga ditentukan peran yang didapat dari keluarga.
\end{abstract}

Pendidikan merupakan salah satu faktor yang sangat penting bagi seseorang untuk dapat meningkatkan kecerdasan, keterampilan, mengembangkan potensi diri dan dapat membentuk pribadi yang bertanggung jawab, cerdas dan kreatif. Pendidikan bukan hanya berasal dari sekolah (formal), tetapi juga dari segi keluarga dan lingkungan (non formal). Kepribadian anak yang berada di tahap perkembangan dan proses pembentukan akan banyak sekali terjadi perubahan atau modifikasi tingkah laku. Konsep tersebut menyerupai pendapat dari Cummins dan Master yang menyatakan bahwa pembangunan sumber daya manusia tergantung pada kondisi lingkungan sekitarnya, keluarga, dan masyarakat (September, Rich, \& N. V. R, 2015). Oleh karena itu, kita perlu mengetahui ciri tingkah laku normal pada setiap tahap perkembangan dan membedakan setiap tingkah laku anak.

Setiap anak memiliki berbagai kebutuhan dasar yang harus dipenuhi untuk memastikan perkembangan menjadi lebih baik. Bukan dari luar saja hal ini perlu diperhatikan, tetapi dari sisi psikologis anak juga perlu diperhatikan. Ilmu psikologi terdapat dua aliran, yaitu psikologi positif dan psikologi negatif. Menurut psikologi negatif, aliran psikologi yang fokus pada fenomena sensasional dan fenomena yang memiliki dampak langsung pada kehidupan, sedangkan psikologi positif merupakan aliran psikologi yang fokus pada pemahaman, penjelasan, dan pengembangan fenomena dan perilaku yang berdampak pada kesejahteraan manusia (Hanurawan, 2016). 
Kenyataan sehari-hari yang kita hadapi, tidak semua anak mengalami perkembangan psikologis yang normal sesuai dengan usia dan rata-rata anak sebayanya. Tentunya tuntutan akan ketersediaan sumber daya manusia yang semakin tinggi dan kualitasnya yang memadai serta output yang berkualitas merupakan suatu hal yang harus dihasilkan oleh sekolah sebagai suatu pendidikan yang tujuan dasarnya adalah menyiapkan manusia-manusia berkualitas, baik secara intelektual, integritas, maupun perannya dalam kehidupan bermasyarakat. Dengan adanya tuntutan tersebut diharapkan pihak keluarga dapat memberikan nilainilai positif bagi anak. Bukan hanya dari pengetahuan, namun dari segi moral juga harus diperhatikan. Hal ini menjadi salah satu tugas utama bagi keluarga. Menurut Kohlberg penilaian moral dikembangkan melalui urutan tertentu untuk mencapai sebuah tahap teratur, misalnya menjadi lebih dewasa, lebih memadai moral dari pendahulunya (Isaksson, 2006). Selain itu, teori ini didasarkan pada interaksi lokal, mempertahankan yang berpikir dan peran mengambil struktur, pengembangan pendidikan yang harus merangsang, muncul secara alami dari interaksi antara anak dan lingkungan di bawah kondisi yang mendorong interaksi seperti itu. Menurut Bloom anak anak pada masa sekarang mengembangkan pemahaman tentang moral difasilitasi oleh interaksi sosial-budaya mereka, pertukaran harian dan negosiasi dengan orangtua, saudara, dan rekan-rekan mereka (Jennifer Cole Wright., Trisha Sedlock., Jenny West., Kelly Saulpaugh. \& Hopkins, 2016).

Perkembangan moral adalah perubahan penalaran, perasaan, dan perilaku tentang standar mengenai benar dan salah. Perkembangan moral memiliki dimensi intrapersonal, yang mengatur aktivitas seseorang ketika dia tidak terlibat dalam interaksi sosial dan dimensi interpersonal yang mengatur interaksi sosial dan penyelesaian konflik (Santrock, 2007). Dengan kata lain, penalaran moral digunakan sebagai penilaian nilai, penilaian sosial, dan penilaian terhadap kewajiban yang mengikat individu dalam melakukan suatu tindakan. Teori Kohlberg ini merupakan dasar dari perilaku etis, memiliki enam tahapan perkembangan yang dapat teridentifikasi. Keenam tahapan perkembangan moral dari Kolhlberg dikelompokkan ke dalam tiga tingkatan, yaitu pra-konvensional, konvensional, dan pasca-konvensional (Hitipeuw, 2009). Teori ini diperkuat dengan pendapat bahwa teori Kohlberg mengikuti perkembangan moral seiring penambahan usia yang semula diteliti Piaget yang menyatakan bahwa logika dan moralitas berkembang melalui tahap-tahap konstruktif (Papalia, 2008). Tahapan-tahapan itu adalah Pra-Konvensional, Konvensional, dan Pasca-Konvensional. Pra-Konvensional mempunyai cakupan usia antara 4-10 tahun, Konvensional mempunyai batasan usia 10-13 tahun atau lebih, sedangkan tahap Pasca-Konvensional biasanya muncul pada usia remaja awal atau usia dewasa awal atau malah tidak sama sekali.

Pada masa sekarang dapat kita ketahui bahwa keluarga memiliki peran yang banyak dalam membentuk moral anak. Dikatakan demikian karena dengan fakta yang ada di lapangan rata-rata anak banyak menghabiskan bersama dengan keluarga dan sisanya bersosialisasi dengan lingkungan sekitar sehingga moral anak pada tahap perkembangan ini dapat didominasi oleh keluarga. Apabila pendidikan di keluarga kurang, maka akan berpengaruh pada perkembangan moralnya pula. Hal ini dinyatakan oleh Burges dan Locke bahwa peran keluarga, struktur keluarga dan komponen keluarga memiliki pengaruh yang tidak diragukan lagi, tetapi hal ini memiliki tantangan dalam penerapannya (Peter Rogers, 2016). Tidak semua anggota keluarga mau diajak kerja sama dalam setiap tahap perkembangan anak. Selain itu, anak memandang orangtua sebagai orang yang memberikan keamanan psikologis bagi diri remaja yang ditunjukkan dengan adanya komunikasi yang baik dan kepercayaan antara orangtua dan anak (Dewi \& Valentina, 2013).

Pada penelitian ini, peneliti tertarik pada peran keluarga dalan perkembangan moral anak di lingkungan eks lokalisasi itu seperti apa. Apakah berpengaruh pada moralnya atau tidak, serta moral seperti apa yang dilakukan oleh anak yang berada pada keluarga di lingkungan eks lokalisasi. Dapat kita lihat lingkungan lokalisasi merupakan lingkungan yang dianggap membawa hal negatif bagi perkembangan anak. Setiap tahap perkembangan, setiap anak dituntut dapat bertindak atau melaksanakan perilaku yang menjadi tugas perkembangannya dengan baik. Ada dua jenis perilaku manusia, yakni perilaku normal dan perilaku abnormal (Kartono, 2000). Perilaku normal adalah perilaku yang dapat diterima oleh masyarakat pada umumnya, sedangkan parilaku abnormal adalah perilaku yang tidak dapat diterima oleh masyarakat pada umumnya, dan tidak sesuai dengan norma-norma sosial yang ada. Perilaku abnormal ini juga biasa disebut perilaku menyimpang atau perilaku bermasalah. Perilaku anak bermasalah atau menyimpang ini muncul karena penyesuaian yang harus dilakukan anak terhadap tuntutan dan kondisi lingkungan yang baru (Hurlock, 2004). Semakin besar tuntutan dan perubahan semakin besar pula masalah penyesuaian yang dihadapi anak tersebut.

Pada umumnya istilah lokalisasi sudah tidak asing bagi telinga orang di Indonesia. Penggunaan istilah lokalisasi sudah memelintir hakikat makna istilah tersebut. Prostitusi merupakan suatu hal yang sulit untuk didefinisikan dari segi kelebihan atau manfaat dari segi praktik maupun ideologi (Hulusjo, 2013). Secara umum, prostitusi merupakan sesuatu yang berhubungan dengan seks untuk uang atau pekerjaan dengan menawarkan jasa pelayanan seksual. Sementara itu, pernyataan lain mengungkapkan bahwa prostitusi adalah kejahatan yang melibatkan dua pelaku, sering dari jenis kelamin yang berbeda (Bucher, Jacob., Michelle Manasse., 2014). Dari pendapat tersebut dapat disimpulkan bahwa lokalisasi merupakan tempat terjadinya suatu kejahatan yang melibatkan dua pelaku dengan jenis kelamin berbeda untuk memuaskan hasrat seksualitas masing-masing.

Tidak sedikit orang menyebutkan apabila anak-anak yang berada di lingkungan lokalisasi memiliki perilaku yang kurang baik. Seperti penyimpangan berikut sesuai dengan fakta lapangan yaitu sorang siswa dengan mudahnya berkata kasar kepada gurunya dan bertindak sesuka hati terhadap siswa perempuan di kelasnya, terbiasa mengumpat seperti orang dewasa, dan mengetahui situs-situs porno di internet. Hal ini dikarenakan apa yang anak lihat akan lebih tertanam dalam ingatan. Selain itu, terdapat fakta lain, seperti seorang anak SD yang menghamili siswi SMP, anak SD yang memiliki kebiasaan menggesek 
kemaluannya di pohon, dan siswa yang dengan tenang menunjukkan alat kelamin kepada lawan jenis (Yohanes, 2018). Dalam hal ini keluarga sangat berpengaruh dalam kehidupan manusia terutama tumbuh kembang seorang anak karena keluarga dapat memengaruhi tingkah laku, pertumbuhan, dan perkembangan. Maka dari itu, keluarga mempunyai peran yang sangat besar untuk memberikan pendidikan awal pada anak, mulai dari anak lahir sampai dapat berinteraksi dengan lingkungan sekitar. Menurut Dewantara, lingkungan pendidikan ialah latar tempat berlangsungnya pendidikan khususnya pada tiga lingkungan utama pendidikan, yakni keluarga, sekolah, dan masyarakat (Tirtaraharja \& La Sulo, 2005).

Lingkungan keluarga menurut Gunarsa yaitu lingkungan yang dialami anak dalam berinteraksi dengan anggota keluarga, baik interaksi secara langsung maupun tidak langsung (Gunarsa, 2009). Suasana keluarga akan berpengaruh bagi perkembangan kepribadian anak. Anak akan mendapatkan perhatian, kasih sayang, dorongan, bimbingan, keteladanan, dan pemenuhan kebutuhan ekonomi dari orangtua sehingga anak dapat mengembangkan segala potensi yang dimilikinya demi perkembangannya di masa mendatang. Keluarga merupakan pengelompokan primer yang terdiri dari sejumlah kecil orang karena hubungan semenda dan sedarah. Keluarga merupakan lembaga pendidikan tertua, bersifat informal, yang pertama dan utama dialami oleh anak serta lembaga pendidikan dimana orangtua bertanggung jawab memelihara, merawat, melindungi, dan mendidik anak agar berkembang dengan baik.

\section{METODE}

Tujuan dari penelitian ini adalah untuk melihat peran keluarga dalam perkembangan moral anak di lingkungan eks lokalisasi. Penelitian ini dilakukan pada bulan Januari di SDN 2 Ngujang yang berlokasi di Kecamatan Ngantru, Kabupaten Tulungagung dengan subjek penelitian dua orang siswa dengan keadaan kondisi keluarga yang berbeda. Penelitian ini menggunakan metode penelitian kualitatif jenis studi kasus. Dalam pengumpulan data, dimulai dari observasi, wawancara, dan dokumentasi. Observasi dilakukan dengan menggunakan jenis partisipasi pasif. Sugiyono menjelaskan partisipasi pasif (passive participation) merupakan pengamatan yang dilakukan peneliti pada kegiatan orang yang diamati, tetapi tidak ikut terlibat dalam kegiatan tersebut (Sugiyono, 2013). Dalam melakukan kegiatan observasi ini peneliti menggunakan lembar observasi. Penggunaan lembar observasi bertujuan agar hal-hal yang diobservasi sesuai dengan fokus penelitian.

Wawancara dilakukan secara mendalam (in-depth) untuk mendapatkan data yang mendalam sesuai dengan fokus penelitian. Menurut Moleong wawancara mendalam merupakan wawancara yang bersifat langsung spontan dan tidak terstruktur (Moleong, 2014). Wawancara dilakukan pada subjek yang terpilih, orangtua dan anggota keluarga dari subjek yang berkaitan dengan perkembangan moral anak. Dokumen digunakan sebagai pendukung informasi dan memberikan bukti relevan pada fokus penelitian. Dokumen dalam penelitian termasuk alat pengumpul data sekunder, yaitu data yang sudah ada pada setting penelitian dan dikumpulkan oleh pihak-pihak lain pada waktu sebelumnya (Moleong, 2014).

\section{HASIL}

\section{Lingkungan Eks Lokalisasi "Ngujang” Kabupaten Tulungagung}

Lingkungan eks lokalisasi "Ngujang" merupakan tempat yang digunakan untuk praktik prostitusi di Kabupaten Tulungagung. Lokalisasi ini sebelumnya sudah ditutup oleh pemerintah daerah, lalu dialihfungsikan menjadi wisata "kethekan" dan warung kopi, tetapi sampai saat ini warga masih menyediakan jasa pelayanan tambahan "hiburan" bagi orang-orang yang mampir untuk minum kopi. Eks lokalisasi ini berada di Kabupaten Tulungagung. Jarak antara rumah peneliti dengan "eks lokalisasi" dapat ditempuh kurang lebih 45 menit dengan kecepatan $\pm 60 \mathrm{~km} / \mathrm{jam}$. Anak-anak di daerah ini mulai memasuki masa pubertas. Kemampuan bersosialisai cenderung cukup baik (dilihat dari perilaku siswa). Berdasarkan hasil wawancara dengan orangtua subjek, mereka telah memasuki masa pubertas, termasuk FT dan SB.

Paparan diatas merupakan gambaran keseluruhan dari karakteristik kedua subjek penelitian. Berikut ini merupakan karakteristik subjek secara personal. Berdasarkan hasil wawancara dan observasi kepada subjek (1) FT merupakan siswa berasal dari keluarga yang sederhana. Ayahnya sudah meninggal beberapa waktu yang lalu. FT anak sulung dari tiga bersaudara. Ia lahir di Tulungagung tanggal 30 Desember 2005. Ia sedikit sulit untuk terbuka dengan orang lain bahkan dengan keluarganya. Ia memiliki kemampuan psikomotor cukup. (2) SB merupakan siswi yang cukup mandiri dan tanggap dengan keadaan sekitar. SB merupakan anak yang cerdas dan bisa diandalkan. Ia merupakan anak ke 4 dari 5 bersaudara. Ia dan keluarganya tinggal di rumah petak dengan ukuran 4m x 4m. Ia memiliki kemampuan psikomotor yang baik. Ia lahir di Kediri 20 Juli 2007.

\section{Paparan Data Mengenai Peran Lingkungan Keluarga}

Lingkungan keluarga yang terlihat sekilas seperti lingkungan keluarga pada umumnya. Mereka tinggal bersama dalam satu tempat tinggal dengan satu kepala keluarga. Pemandangan yang membedakan adalah pada saat menjelang malam hari. Pada pukul tertentu di sekitar tempat tinggal tersebut "mbak" yang bekerja sudah siap untuk menerima tamu. Peneliti juga melakukan observasi ke rumah subjek penelitian untuk melihat secara langsung interaksi subjek dengan keluarga. Berikut ini mengenai peran dan interaksi subjek dengan anggota keluarga lainnya. 


\section{Peran dan Interaksi Subjek FT dengan Anggota Keluarga}

Dari peran lingkungan keluarga, menunjukkan bahwa keluarga FT cenderung lebih acuh dan memberi kebebasan terlalu besar kepada FT. Acuh yang dimaksudkan disini seperti kurangnya keharmonisan dan komunikasi dalam keluarga. Dari penelitian ini ditemukan bahwa AS selaku anak pertama dan kepala keluarga menyebutkan bahwa keadaan seperti ini sudah biasa dalam keluarga mereka. Misalnya seperti saat FT tidak mengikuti sholat jumat, pihak keluarga membiarkannya. Mereka tidak mengarahkan karena menganggap hal itu tidak terlalu menjadi masalah. Pada kenyataannya FT telah baliq. Selain itu menurut penuturan kakak perempuan FT, di bulan ramadhan saat melaksanakan sholat tarawih FT dan teman-temannya ramai bahkan saling menggoda satu sama lain. Meskipun sudah ditegur masih tetap bertingkah.

AS atau anggota keluarga yang lain tidak mempermasalahkan atau memaksa FT untuk ikut mengaji yang diadakan di lingkungan sekitar, ikut acara gotong royong dan bersosialisasi dengan tetangga sekitar. Selain itu, sikap sopan santun yang ditunjukkan FT dapat dikatakan kurang. Hal ini terbukti dari sikapnya yang suka membangkang orangtua, suka mengucapkan kata kasar, dan bersikap sesuka hati. Pihak keluarga FT merasa hal yang dilakukan FT wajar di usia yang masih suka bermain.

Selain pemalu, FT tidak jarang merasa minder, tetapi merasa berkuasa diantara teman-temannya, pasalnya karena FT sebenarnya sudah kelas VII SMP tetapi masih duduk di kelas V sehingga ia terlihat lebih egois daripada yang lainnya. Rasa berkuasa yang dimiliki FT juga terjadi di lingkungan keluarga karena ia merupakan anak sulung dan merasa belum memiliki kewajiban. Menurut penuturan pihak keluarga, FT tertangkap beberapa kali mengucapkan kata-kata kasar kepada saudara yang lebih tua atau muda. Pihak keluarga sebenarnya sudah memberikan arahan dan nasehat kepada FT, tetapi respons yang ditunjukkan FT berupa sikap penolakan atau sikap acuh (Sugiyono, 2013).

Dari pihak keluarga sudah memberikan teladan bagaimana harus bertanggung jawab, saling menghargai, empati, dan sebagainya, tetapi untuk feedback yaang diberikan oleh FT tidak sesuai dengan harapan keluarga. Pihak keluarga akhirnya membiarkan FT berkembang dengan sendirinya sehingga pihak keluarga tidak begitu menekan FT. Tanpa adanya hukuman atau punishment kepada FT agar bisa lebih baik. Mereka yakin nantinya FT dapat menyadari dan memilah mana yang baik dan buruk. Meskipun seperti itu dari keluarga juga tetap mengawasi dan memperhatikan FT agar tidak menyimpang atau terjerumus dengan sesuatu yang kurang baik. Demikian penjelasan dari kakak pertama. Meskipun beliau termasuk orang yang sedikit bicara, tetapi beliau cukup membantu penelitian ini. Seluruh anggota keluarga FT memang termasuk orang-orang seperti itu, tetapi tidak menutupi kesan ramah kepada setiap orang.

\section{Peran dan interaksi subjek SB dengan anggota keluarga}

Rasa kekeluargaan cukup kuat di keluarga SB dan kedua saudaranya tinggal bersama orangtua kandung di rumah petak dengan ukuran $4 \mathrm{~m}$ x 4m. Hanya terdapat satu ruangan yang dijadikan sebagai ruang multifungsi. Rasa kekeluargaan dan keharmonisan dari keluarga ini cukup terasa baik dengan keterbatasan ekonomi yang sedang dialami. Dibalik keterbatasan yang dialami keluarga SB, mereka tidak melupakan untuk tetap mendampingi perkembangan anaknya. Meskipun orangtuanya bekerja serabutan, dari pendidikan agama yang diberikan juga tidak sedikit. SB dan kedua saudaranya ikut kegiatan TPQ di musholla terdekat. SB dan adiknya juga sering membantu membersihkan musholla bersama teman-teman. Hal tersebut dilakukan orangtua SB karena mereka merasa belum cukup banyak dalam ilmu agama sehingga mereka pasrahkan kepada pihak-pihak yang lebih memahami agama. Bukan hanya dari ilmu agama, tetapi pihak keluarga juga memberikan tanggung jawab kepada setiap anggota, seperti bersih-bersih rumah, menyapu, mencuci piring, dan mencuci baju. Jika ada yang sudah selesai, anggota keluarga yang lain juga membantu.

Pemberian tugas tersebut bertujuan untuk melatih rasa tanggung jawab dan disiplin sejak dini. Ayah SB tidak membedakan perlakuan kepada setiap anak-anaknya. Ia juga memberi sanksi kepada SB dan saudaranya jika mereka berbuat salah atau tidak jujur. Hukuman yang diberikan masih dalam tahap wajar. Menurut ayah SB, kejujuran dan tanggung jawab itu penting. Harus dari kesadaran diri bukan hanya karena takut kepada suatu hal dan ia juga selalu mengingatkan kepada seluruh anggota keluarga untuk bersikap rendah hati, tetapi tidak menjatuhkan harga diri. Selain itu, ayah SB mengajarkan dan malatih anak-anaknya untuk menyelesaikan segala permasalahan dengan cara musyawarah, bukan dengan emosi. Jika dalam suatu permasalahan belum ada keputusan, jangan ragu mengajukan diri untuk mencari jalan tengah. Sejak kecil orangtua SB mengajarkan untuk tidak melihat orang dari pekerjaan atau materi. Mereka mengajarkan kepada SB untuk tidak pilih kasih kepada siapapun. Berdasarkan keseluruhan data mengenai peran keluarga dalam perkembangan moral siswa di lingkungan eks lokalisasi Kabupaten Tulungagung cukup baik. Keluarga tidak melarang bergaul dengan siapapun, namun selalu memberi nasihat. Keluarga memberi contoh mana yang baik dan buruk, tetapi mereka tidak mengajarkan untuk membedakan setiap orang. Apalagi membedakan dari pekerjaan maupun latar belakang.

Paparan di atas dapat diambil kesimpulan bahwa peran lingkungan keluarga FT belum sepenuhnya, belum sesuai dengan taraf pra-konvensional yang dikemukakan oleh Kohlberg. Keluarga FT memang telah menerapkan peraturan dalam kehidupan sehari-hari, tetapi tidak ada punishment yang diberikan kepada anak sehingga tindakan yang seharusnya perlu pembenaran tidak terlalu diperhatikan oleh FT dan dianggap merupakan sesuatu yang tidak penting. Sementara itu, keluarga SB sangat antusias untuk mendidik dan menjadikan anak-anaknya lebih baik dari dirinya. Mereka berusaha untuk memberikan bekal yang baik. Pembagian hak dan kewajiban, punishment diterapkan sesuai porsinya. 


\section{Temuan Penelitian Mengenai Peran Lingkungan Keluarga}

Peran lingkungan keluarga cukup mendukung. Setiap keluarga memiliki cara mendidik putra putrinya. Subjek juga merasa baik-baik saja dengan cara mendidik dari keluarga masing-masing. Berikut ini temuan penelitian dari masing-masing subjek penelitian.

\section{Subjek FT}

Berdasarkan paparan data yang dideskripsikann oleh peneliti, temuan penelitian mengenai peran keluarga bagi FT yaitu keluarga selalu mendukung apa yang dilakukan asalkan dalam kegiatan positif. Keluarga cukup memberi kebebasan berteman dengan siapapun. Peran keluarga yang diberikan kepada FT telalu dibebaskan, dalam artian terlalu dimanja dalam kehidupannya. FT kurang diberikan tanggung jawab dan penerapan norma-norma yang berlaku kurang diterapkan. Namun, pendapat dari warga sekitar tempat tinggal FT mengungkapkan bahwa keluarga FT cukup disegani di lingkungan tersebut, meskipun hubungan FT dengan keluarganya tidak terlalu dekat.

Penerapan nilai-nilai moral yang ada dalam kehidupan sehari-hari terbilang kurang baik. Hal ini dibuktikan dari tingkah laku dan ucapan FT di lingkungan keluarga. FT memang takut kepada saudara laki-lakinya, tetapi ia tidak sungkan mengucapkan kata kasar jika sudah emosi. Saudara laki-laki FT memang tergolong sabar dan tegas, sehingga FT masi suka membantah. Kepada saudara perempuannya FT semakin tidak takut bahkan tidak sungkan. Rasa patuh dan hormat yang dilakukan kepada saudaranya terbilang masih kurang. Sebagai ibu yang sudah lansia dan sering sakit sepeninggal ayah FT, beliau tidak dapat berbuat tegas seperti dulu. Suara beliau yang semakin kecil membuatnya susah untuh berkomunikasi dengan baik dengan putra sulungnya.

\section{Subjek SB}

Berdasarkan paparan data yang dideskripsikan oleh peneliti, temuan penelitian mengenai peran keluarga bagi SB yaitu menunjukkan bahwa orangtua selalu mengusahakan yang terbaik untuk anaknya. Meskipun dari segi perekonomian dan pendidikan tergolong rendah. Tetapi mereka mengajarkan pengetahuan untuk masa depan anak. Pendidikan yang diberikan dari keluarga juga bagus, semua anggota keluarga saling mendukung satu sama lain. Anggota keluarga sadar dengan tanggung jawab masing-masing sesuai dengan peran mereka. Penerapan nilai-nilai moral dalam kehidupan sehari-hari cukup baik.

Berdasarkan temuan data dari kedua subjek diatas dapat dilihat bahwa secara umum peran lingkungan keluarga belum sepenuhnya mencapai taraf pra-konvensional yang disebutkan oleh Kohlberg. Untuk punishment dan reward sudah terlihat, tetapi masing-masing keluarga memiliki perbedaan yang signifikan. Dari keluarga FT terlihat jelas punishment yang jarang diberikan, sedangkan keluarga SB selalu ada punisment yng bertujuan untuk mendisiplinkan. Pihak FT memberikan reward yang cukup sering dengan tujuan FT tidak merasa iri dengan temanya. Akan tetapi, sikap ini tidak diimbangi dengan arahan yang tegas kepada anak sehingga FT merasa apa yang dia dapat karena hak sebagai anak sulung.

Rasa tanggung jawab kepada reward yang diberikan juga kurang. Pihak keluarga sering menemukan barang-barang yang asal dibeli karena ikut gaya-gaya seperti teman-temannya, sedangkan SB harus sabar jika ingin suatu reward. SB menceritakan keluarganya memang jarang memberikan hadiah jika menang lomba atau semacamnya. SB lebih sering menerima ucapan selamat, terimakasih, dan motivasi yang sama.

\section{PEMBAHASAN}

Peran keluarga pada perkembangan moral anak di lingkungan eks lokalisasi cenderung cukup baik. Peran keluarga di lingkungan eks lokalisasi juga beragam. Hal ini dikarenakan latar belakang dan kebiasaan yang ada di keluarga sehari-hari, karena tidak semua adalah penduduk asli di lingkungan tersebut. Interaksi yang terjalin antara penghuni lokalisasi dengan masyarakat sekitar lokalisasi dapat memberikan dampak dan pengaruh yang negatif kepada anak-anak dan masyarakat yang berada disekitar lokalisasi (Rusdiana, 2014). Latar belakang dan kebiasaan ini dapat menyebabkan perkembanagan anak berdampak positif atau negatif. Terbukti pada aktivitas dan kegiatan anak sehari-hari. Selain itu, lingkungan sosial yang kurang baik dapat memberikan input yang kurang baik bagi perkembangan moral anak sehingga anak-anak perlu dibekali dengan keterampilan emosi dan sosial supaya mereka mampu mengenali, mengolah, dan mengontrol emosi (Purwanti, 2010). Selain kenyataan bahwa seks bebas menjadi pemandangan yang biasa di lingkungan eks lokalisasi tersebut, didalamnya juga sering terjadi peristiwa-peristiwa penganiayaan, pemerasan, penyalahgunaan obat terlarang atau miras, serta berbagai bentuk kejahatan lainnya (Issabela \& Hendriani, 2010).

Peran keluarga yang diberikan kepada FT cukup komunikatif dan mendukung perkembangan moral anak. Suasana di keluarga FT cukup baik dan kondusif. Terbukti pada aktivitas yang dilakukan FT sehari-hari tidak jauh berbeda dengan apa yang biasa dia lihat dan terima dari keluarga. FT cukup pemalu dan hanya berbicara seperlunya apalagi dengan orang yang baru dia kenal. Cukup sulit juga untuk melakukan pendekatan dengan pihak keluarga FT. Keluarga FT memang memberikan arahan dan nasehat setiap hari, tetapi hal tersebut dirasa kurang mendukung peran keluarga sepenuhnya. Keluarga FT terlihat acuh dengan sikap FT sehari-hari. Bagi mereka asalkan FT tidak membuat masalah berat, mereka tidak teralu mempermasalahkannya. Selain itu, untuk rasa tanggungjawab dan toleransi masih belum terlihat. Hal ini juga diungkapkan oleh keluarga FT. Dari pihak keluarga seakan memberikan kebebasan kepada subjek sehingga peran yang seharusnya dapat dimaksimalkan menjadi 
berkurang. Meskipun penghambat peran tersebut karena pekerjaan, tetapi alangkah baiknya tentang tanggung jawab dan toleransi lebih diperhatikan, apalagi dengan kondisi lingkungan seperti itu.

Untuk subjek SB, ia memiliki kemampuan komunikasi yang cukup baik dengan orang-orang yang ia baru kenal. Rasa tanggungjawab dan toleransi sudah terlihat dalam aktivitas sehari-hari. Namun, sikap positif yang diterapkan oleh keluarga SB harus perlu pengawasan. Hal ini dikarenakan aktivitas dan kegiatan setiap harinya berhubungan langsung dengan PSK maupun pelanggan. Hubungan yang kurang baik dengan keluarga atau orangtua dapat menyebabkan pengawasan kepada anak menjadi kurang sehingga muncul kurangnya penegakan disiplin, tanggung jawab, toleransi dalam kehidupan sehari-hari. Hubungan orangtua dengan anak yang baik dapat menghasilkan penegakan disiplin di rumah secara non-formal. Selain itu, hubungan yang baik dapat memberikan self regulation yang baik kepada anak. Regulasi diri yang kurang efektif dapat menimbulkan perilaku agresif, sedangkan individu yang memiliki regulasi diri efektif akan lebih mampu mengendalikan dirinya (DeWall, 2007). Hasil penelitian lain menyebutkan bahwa regulasi diri dapat menjadikan seseorang mengendalikan perilaku maladaptive (Trentacosta \& Shaw, 2009).

\section{SIMPULAN}

Penelitian mengenaiperan keluarga dalam perkembangan moral anak di lingkungan eks lokalisasi ini terlihat bahwa peran lingkungan keluarga dalam perkembangan moral anak sangat penting. Dari keluarga, setiap anak akan mendapatkan ilmu yang tidak ditemukan di lingkungan pendidikan formal. Lingkungan keluarga berperan dalam mengatur kehidupan seorang anak. Mengatur bagaimana anak akan tumbuh berkembang dalam kehidupan sehari-hari. Lingkungan keluarga menjadi pondasi dalam setiap perkembangan anak. Baik buruk perkembangan anak juga ditentukan peran yang didapat dari keluarga.

Dari hasil penelitian yang telah dilakukan mengenai peran keluarga dalam perkembangan moral anak di lingkungan eks lokalisasi, maka peneliti memberikan saran untuk memberikan perhatian lebih kepada subjek peneliti untuk memantau dan mengawasi setiap tahap perkembangan anak. Meskipun dari lingkungan sekolah atau masyarakat mereka mendapat pengetahuan baru, namun keluarga yang harus mengontrol perkembangan anak.

\section{DAFTAR RUJUKAN}

Bucher, Jacob., Michelle Manasse., J. M. (2014). No Soliciting Strain: Examining Both Sides of Street Prostitution Through General Strain Theory. Journal of Crime and Justice, 1-19. https://doi.org/10.1080/0735648X.2014.949823

DeWall, C. (2007). Violence Restrained: Effects of Self-Regulation and its Depletion on Aggression. Journal of Experimental Social Psychology, 62-76. https://doi.org/10.1016/j.jesp.2005.12.005

Dewi, A. A., \& Valentina, T. D. (2013). Hubungan Kelekatan Orangtua-Remaja dengan Kemandirian pada Remaja di SMKN 1 Denpasar. Jurnal Psikologi Udayana, 1(1), 181-189. https://doi.org/10.24843/JPU.2013.v01.i01.p18

Gunarsa, S. D. (2009). Psikologi untuk Keluarga. Jakarta: Gunung Mulia.

Hanurawan, F. (2016). Perspektif Alternatif Dalam Psikologi Pendidikan. Malang: Universitas Negeri Malang.

Hitipeuw, I. (2009). Belajar dan Pembelajaran. Malang: Universitas Negeri Malang.

Hulusjo, A. (2013). No Experience, A Critical Perspective on Difference: 'The Prostitute' and Women with Prostitution Title. Nordic Social Work Research, 1-184. https://doi.org/10.1080/2156857X.2013.809015

Hurlock, E. B. (2004). Perkembangan Anak Jilid 1. Jakarta: Erlangga.

Isaksson, A. (2006). Kohlberg's Theory of Moral Development and Its Relevance to Education. Scandinavian Journal of Educational Research, 47-63. https://doi.org/10.1080/0031383790230202

Issabela, N., \& Hendriani, W. (2010). Resiliensi pada keluarga yang tinggal di Lingkungan Lokalisasi Dupak, Bangunsari. Jurnal INSAN, 12(3), 176-186.

Jennifer Cole Wright., Trisha Sedlock., Jenny West., Kelly Saulpaugh., M., \& Hopkins. (2016). Located in the thin of it: Young Children's Use of thin Moral Concepts. Journal of Moral Education, 1-16. https://doi.org/10.1080/03057240.2016.1156523

Kartono, K. (2000). Psikologi Abnormal. Bandung: Mandar Maju.

Moleong, L. J. (2014). Metodologi Penelitian Kualitatif. Bandung: Remaja Rosdakarya.

Papalia, D. (2008). A Child's World: Infancy Through Adolescence. New York: McGraw-Hill.

Peter Rogers. (2016). Family is Not an Institution: Distinguishing Institutions from Organisations in Social Science and Social Theory. International Review of Sociology, 1-16. https://doi.org/10.1080/03906701.2016.1235214

Purwanti. (2010). Mengembangkan Kecerdasan Emosional pada Anak Taman Kanak-kanak sebagai Upaya Menciptakan Anak Cerdas, Ceria, dan Berakhlak. Jurnal Visi Ilmu Pendidikan, 2(1),

Rusdiana. (2014). Interaksi Sosial Pekerja Seks Komersial Lokalisasi Bandang Raya dengan Masyarakat Kelurahan Mogirejo, Kota Samarinda. Ejournal Ilmu Sosiatri, 1-17.

Santrock, J. W. (2007). Child Development. (M. R \& A. K, Eds.) (Eleventh). Jakarta: Erlangga.

September, S. J., Rich, E. G., \& N. V. R. (2015). The Role of Parenting Styles and Socio-Economic Status in Parents'

Knowledge of Child Development. Early Child Development and Care, 1-9.

https://doi.org/10.1080/03004430.2015.1076399

Sugiyono. (2013). Metode Penelitian Kuantitatif, Kualitatif dan RND. Bandung: Alfabeta. 
Tirtaraharja, U., \& S.L. La Sulo. (2005). Pengantar Pendidikan. Jakarta: Rineka Cipta.

Trentacosta, C. ., \& Shaw, D. (2009). Emotional Self-Regulation, Peer Rejection, and Antisocial Behavior: Developmental Associations from Early Childhood to Early Adolescence. Journal of Applied Developmental Psychology, 356-365. https://doi.org/10.1016/j.appdev.2008.12.016

Yohanes, D. (2018). Ayah Bocah SD Tulungagung Sebut Siswi SMP yang Hamil Itu Percobaan Seksual Anaknya yang Baru Sunat. Radar Tulungagung, p. 4. 